\title{
利用者出現率の均等化から見た施設配置訃画の研究 (2)
}

\author{
一一各種施設の利用者出現摔の均等化— \\ （社会教育, 福祉, 体育施設の研究・その 5)
}

正会員渡辺昭应水

\section{§1. 研究の目的と調查の方法}

\section{1. 研究の目的}

地域公共施設は従来生活補導的な意味 (生活困窮者や 身体障害者等に対する施設等) を強く持っていたが，生 活水準の全体的な向上などによって近年それに変化が見 られ，一般住民が利用する公共施設も多種多地域に設け られることが多くなった。これに対して地域公共施設の 研究は公共施設の中でのサービスの質と地域に対しての サービスの量の研究が見られ, 前者は従来から行なわ れ，各種の研究の成果が報告されている使われ方の研究 がこれに該当し，後者は多様な施設をどのような観点に 立って施設を設立する地域の選択，建設順序の決定を行 なえばよいかについての方法論等を含んだ研究で，これ は現在各種検討されている段階と言える。本報告はその 後者についての研究で，その一つの方法として施設が設 置された場合の地域に扣ける利用者出現率の差に注目 し，地域公共施設は本来公共のサービスとして住民に利 用の機会を均等に与えなければならないという観点にた って各種の地域公其施設について分析する。なお，利用 者出現率は施設から利用者の住所をでの直線距離別に 1 年間に施設の対象階層人口 1 人当りが利用した比率によ って示す。また，本報告は前報告「利用者出現摔の均等 化からみた施設配置計画の研栄」(1) 一各種施設の利用 者出現率のモデル化と比較に続くものである。具体的に は社会教育施設として青年館，青年の家，公民館，読書 室, 図畫館; 社会体育施設として体育館, プール，社会 福祉施設として老人福祉センター, 老人クラブ, 勤労青 少年ホーム，児童厚生施設として児童館について分析を 行なら。

\section{2. 調查の方法と時期}

調查は施設にインタビュ一調查を行ない，年間の利用 者人数等を調へ，利用者住所については施設に入館証等 の形で資料がある場合にはそれを転記し，ない場合は一 定期間の利用者にアンケート調查を行なった。調查時期 は青年館は昭和 42 年 8 月, 公立青年の家は昭和 43 年 $\mathbf{9}$

\footnotetext{
* 東京都立大学大学院博士課程
}

(昭和 47 年 9 月 12 日本稿受理 ・討諭期限昭和 48 年 6 月末日)
月, 公民館は昭和 45 年 11 月, 読畫室は昭和 42 年 8 月, 図書館は昭和 43 年 8 月と昭和 45 年 11 月, 体育館は昭 和 44 年 8 月，プールは昭和 44 年 8 月，老人福祉センタ 一は昭和 45 年 11 月, 老人クラブは昭和 42 年 8 月, 勤 労青少年ホームは昭和 44 年 11 月, 览童館は昭和 41 年. 8 月に行なった。

\section{§ 2. 複数施設設置における施設間距離}

単独の各施設の利用者出現率については前報告で分析 し, 運営方法等によっては単独の施設でも地域の利用者 出現率の均等化を計れることを分析したが，単独の施設 のみによってでは地域の大きさにもよるが限界があり， 複数の施設の設置によって均等化を計る必要がある。そ の場合に複数の施設間の距離をどのように決めるかにつ いては, 現状の施設の利用者出現率の最高值との関連で その何分の幾つかを確保できるように決める方法や，単 純に $50 \%$ 距離（全利用者の $50 \%$ が利用する圈域の半 径) $75 \%$ 距離等で行ならなど各種の方法がある。こ こでは地域公共施設は本来公共のサービスとして住民に 利用の機会を均等に与える必要があるという観点で, シ ビルミニマム的な考えを導入し，どの地域に㧊いても利 用者出現率を最低 1.0 とするような施設配置を求める。 (階層人口 1 人当り年間に 1 回は利用できる)。そのため には複数化の場合 2 施設の利用者出現率の 0.5 の地城が 重なるように施設閒距離を決めることになる。もちろん その施設の利用階層, 利用形態によってはそれに近ずけ ることさえ難かしい施設もあるが，それについてはその 施設の項で分析する。また，これによってでも均等化に は十分でないが，次の段階として考えることができる。 施設間距離を決める利用者出現率のデーターとしては, 各種施設について距離別平均利用者出現率を用い，これ は各種施設の各施設について一定期間の利用者の住所を 地図上にプロットし，これを施設までの直線距離別に利 用者数を整理する。さらに, その結果に調査可能であっ た利用者数で年間の利用者数を割った数字をかけて，年 閒の直線距離別の利用者数とした。これを直線距離別の 階層人口（市等の施設の場合は地図に昭和 40 年国勢調 查による人口集中地区，非人口集中地区の璄界を記入 
し，施設からの距離別の円環ごとに人口集中地区，非集 中地区の面積をプラニメーターで測定した。また，それ ぞれの地区の施設の対象階層人口密度を求めるため, 国 調により人口集中地区，非集中地区の全人口密度にその 市の全人口に対する施設の利用階層の比率を加けて求め たた。それを前出の面積にそれぞれかけて直線距離別の 階層人口を算出した。また，広域な利用が行なわれる施 設については昭和 40 年国調から施設の対象階層人口を 市ごとに求め，それを地図にプロットし，施設からの直 線距離別に整理した）で割り, 直線距離別の施設の対象 階層人口 1 人当りが年間に利用する確摔を計算したもの である。それをさらに同種の施設について各施設の主要 な利用者出現率 $(1.0 ， 0.5 ， 0.1 ， 0.01)$ における利用 距離と利用者構成比率を求め, それぞれ各種施設間で平 均して, 平均利用者出現率, 平均利用者構成比率を求め た。これを図一1〜11 に示すと図のように示せ，これに より平均利用者出現摔 0.5 の利用距離を求め, この倍の

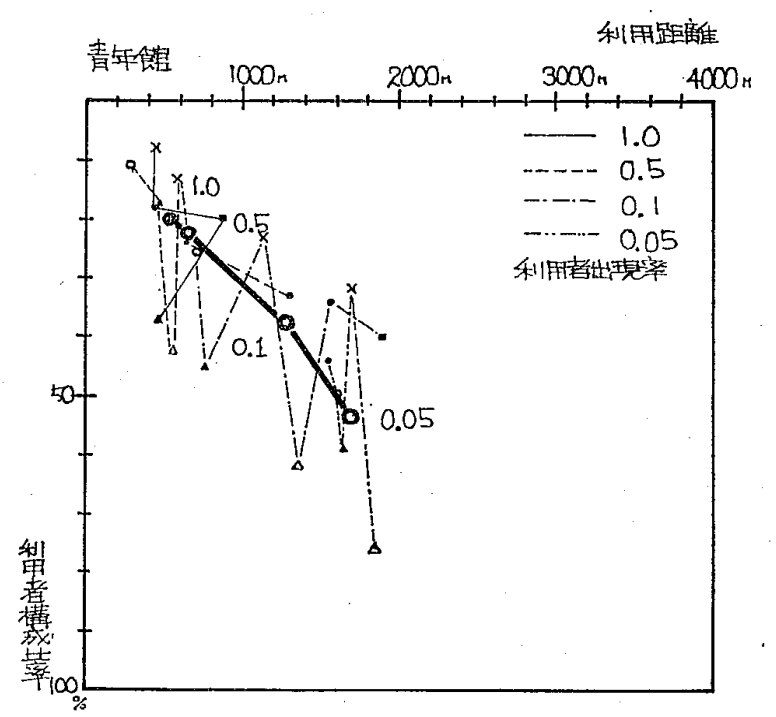

図一1 青年館の利用者出現率と利用者構成比率 之利用距離

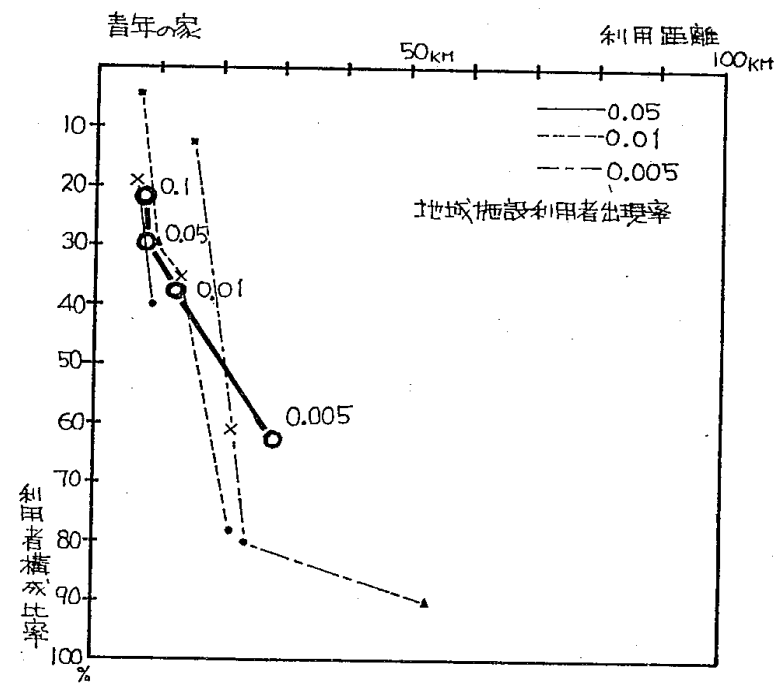

图一2 青年の家の利用者出現率と利用者構成此率 乙利用距離

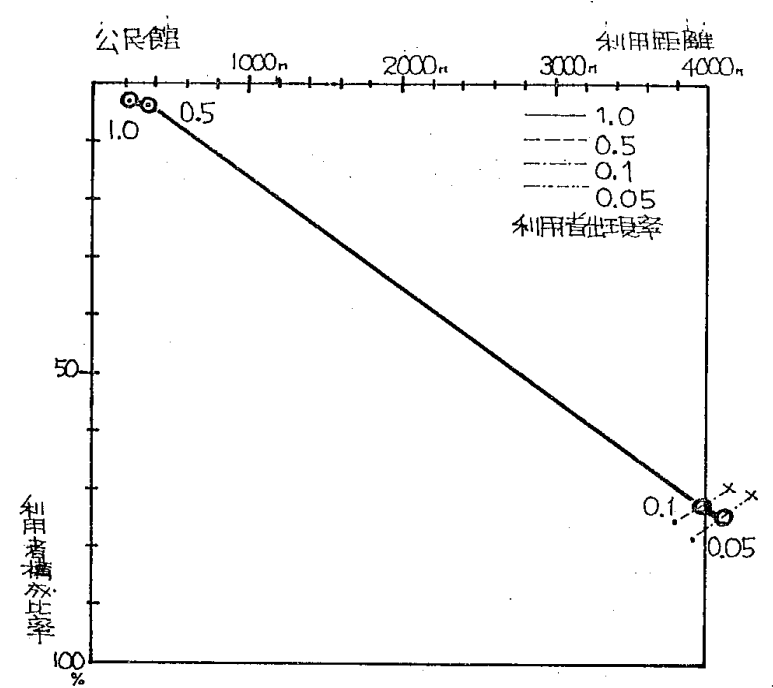

図一-3 公民館の利用者出現率々利用者棈成比率 之利用距離

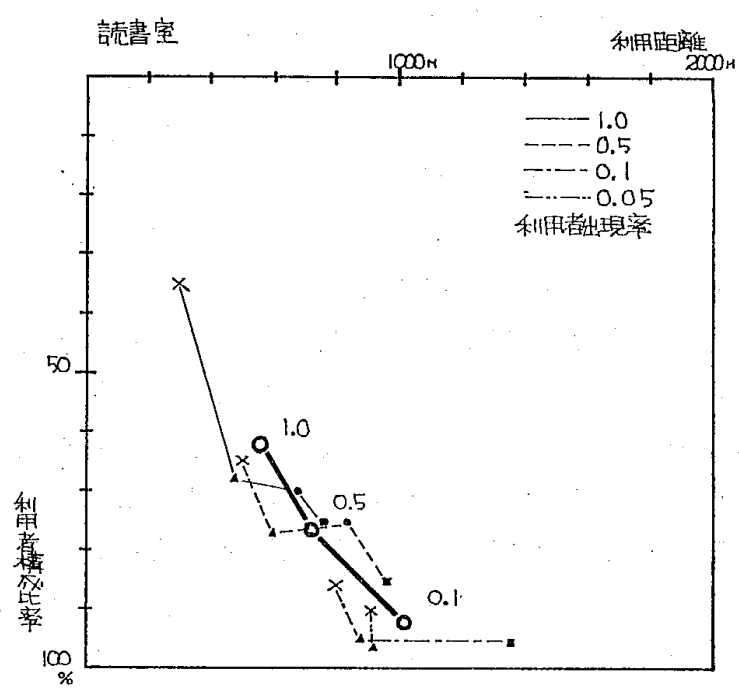

図一4 読畫室の利用者出現率と利用者棈成比率 と利用距離

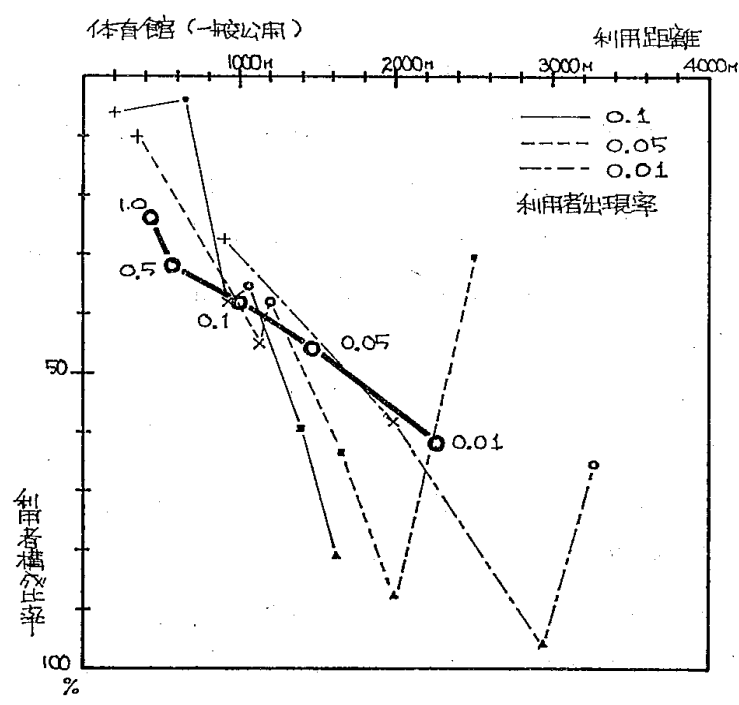

图一5 図書館の利用者出現率子利用者構成比率 と利用距離 


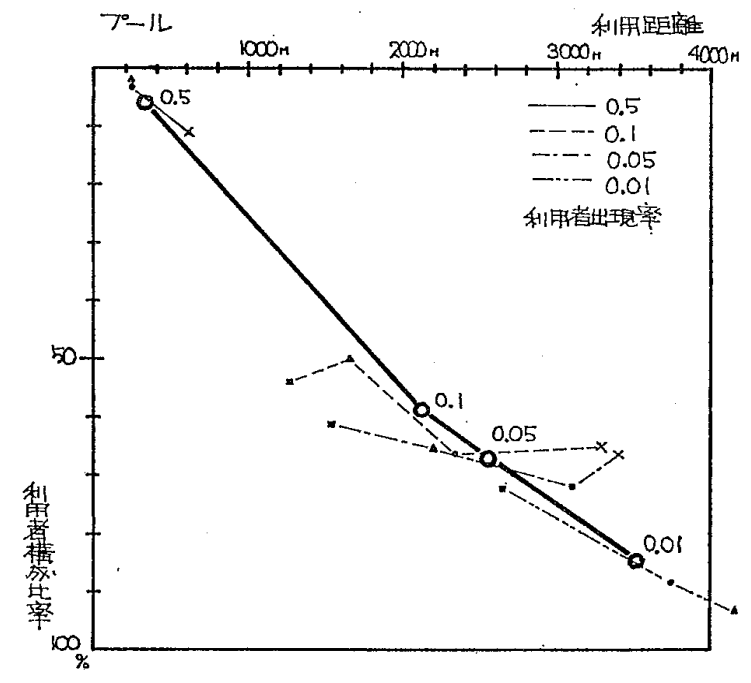

図一6 体育館の利用者出現率と利用者構成比率 と利用距離 (一般公開)

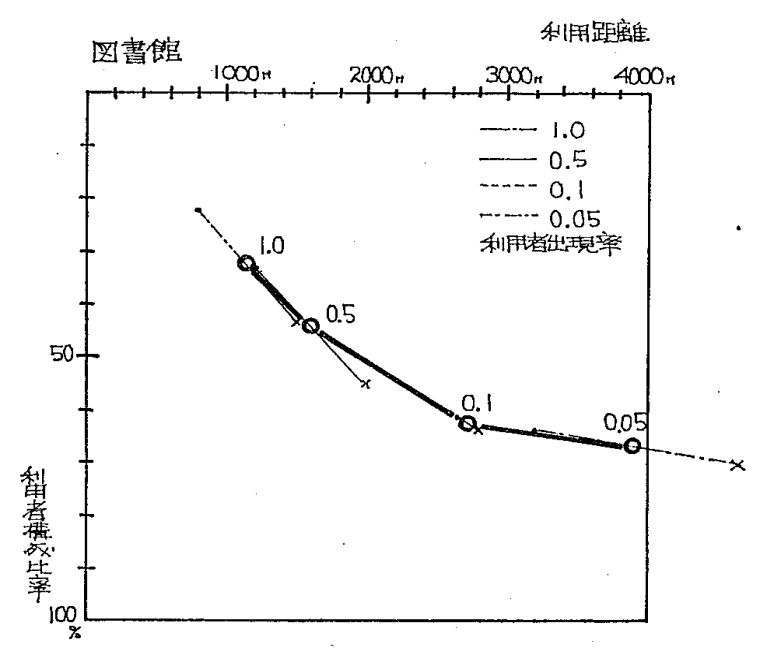

図一7 プールの利用者出現率と利用者構成比率 と利用距離

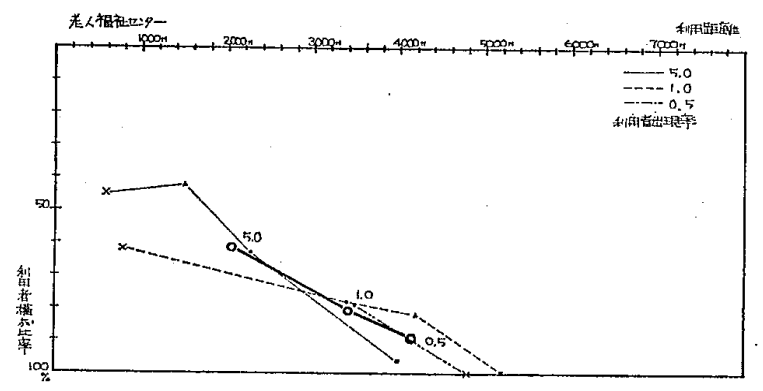

図一8老人福祉センターの利用者出現率 之利用者構成比率と利用距離

距離を施設の複数化により平均利用者出現摔の最低を 1.0 とするための施設間距離とした。以上の結果を整理 すると表一1 のように整理できる。

これらの例の中で 1 施設による利用者出現摔 0.5 まで の利用者構成比率が過半を占めているのは読書室, 老人 福祉センター, 老人クラブ, 勤労青少年ホーム, 児童館 で，これらの施設はいずれも個人利用施設で利用形態の 上からは一般的には周辺の利用者の多い施設で，この比 率を示していると言える。逆に利用者構成比率が少ない

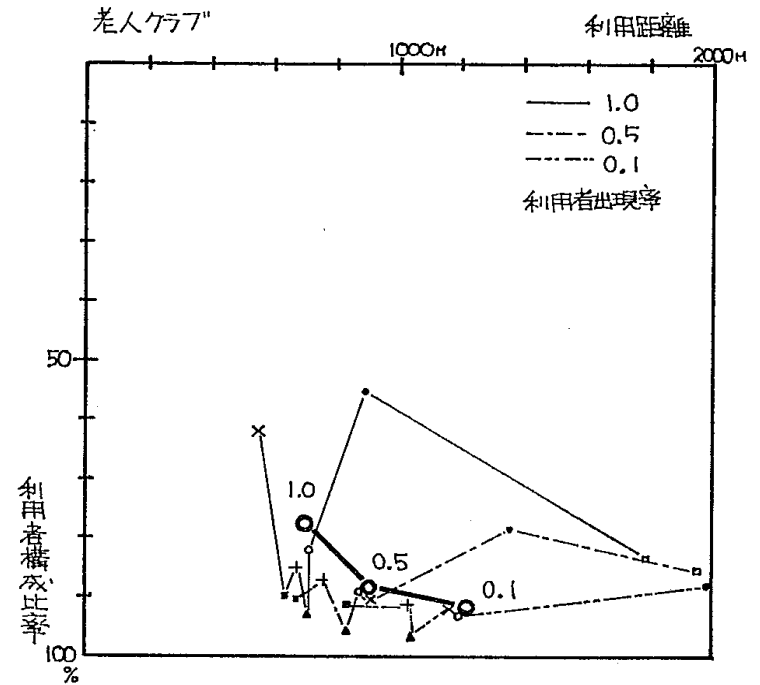

図一9老人クラプの利用者出現率と利用者構成比率 と利用距離

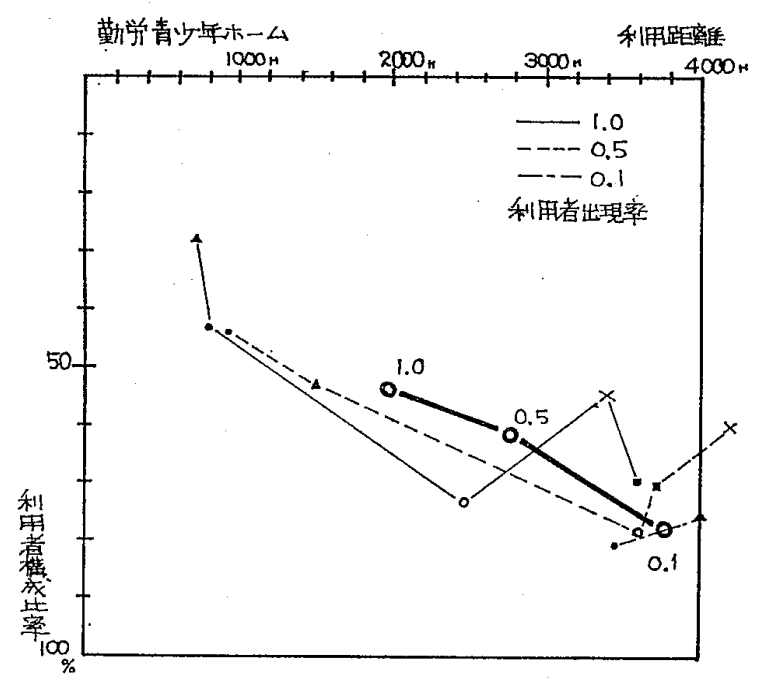

図一10 勤学青少年ホームの利朋者出現率 と利用者構成此率と利用距離

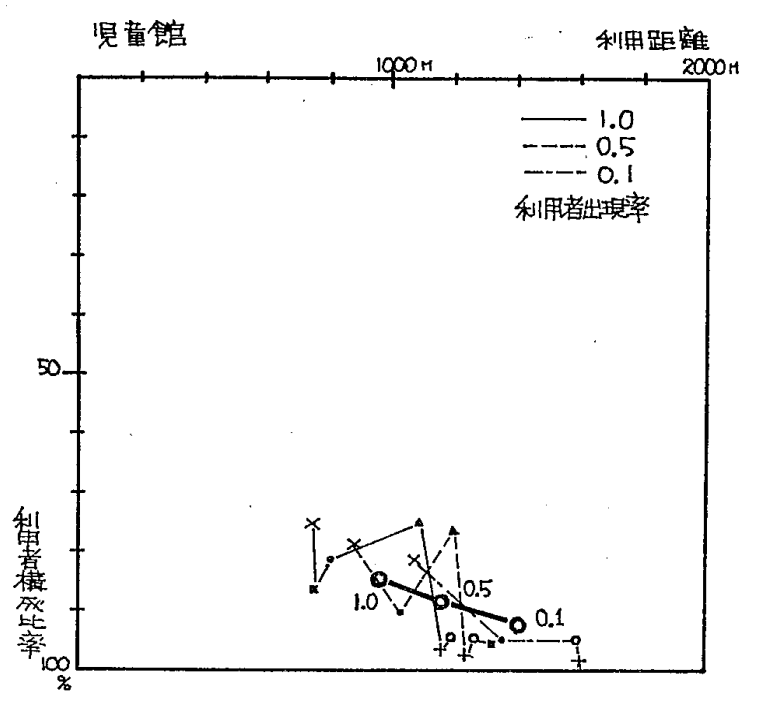

図一-11坚童館の利用者出現率と利用者構成比率 と利用距離

施設の中で青年館, 青年の家, 公民館については, グル 一プ利用が利用の中心で，おもにグループ構成員が同一 の圏域の中にいることが少ないため，また青年の家につ 
表一1 各種施設の複数化のための施設間距離

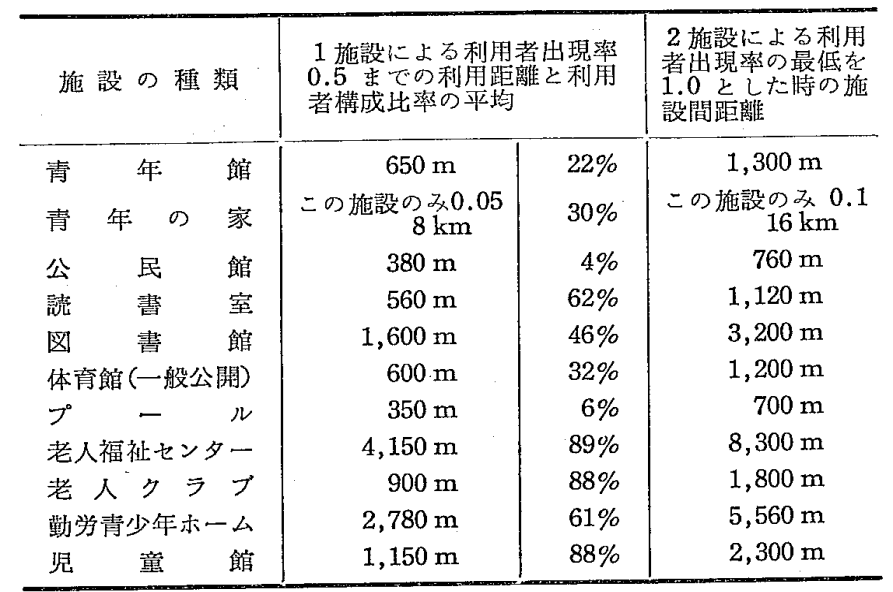

いては特にその利用形態が宿泊利用で，他と異なり遠距 離からでも利用するためにこの結果になっていると考え られる。また, 図書館, 体育館 (一般公開を含屯個人利 用), プールは個人利用が 中心の施設であるのに，前記 の個人利用施設に較べて利用者構成比率が少ないのは， おるにその利用層が薄く広域に広がっているためと言 え，特にプールがそらであると言える。以上を考慮して 各種施設の施設間距離を見ると，これらの中で最も施設 間距離の大きいのは青年の家で, 次いで老人福祉センタ 一, 勤労青少年ホーム, 図畫館, 児童館, 老人クラブ, 体育館 (一般公開), 読書室, 公民館, プールの順となっ ている。老人福裃センターの施設間距離が勤学青少年木 一ム等より大きいのはやや意外であるが，調査した施設 の中にバスを利用して遠距離の利用者を集める施設や， 他市と連携して事業を行なって㧍り他市の人達がかなり 利用に来る施設等が含まれているため，それらの施設の 影響で施設間距離が大きくなっていると考えられる。

\section{§3. 複数施設設置による地域利用者出現率の均等化}

前章に扔いては利用者出現率が最低 1.0 となるような 施設間距離を求めるという作業を行なった結果を分析し たわけであるが，ここでは実際に施設が複数化されてい る場合にその複数化の状況により，各地域の利用者出現 率がどのような状況であるか, 特にどのように利用者出 現率が均等化されているかについて分析する。複数施設 の設置による地域利用者出現率は，各施設についての円 環状の利用者出現率をそれぞれ施設の立地している位置 を中心に書き，それを加えることによって求めた。な 掠, 分析は東京都目黑区の老人クラブ 7 施設, 江東区読 書室 4 施設, 大田区青年館と働く青年の家, 埼玉県の 6 施設のうちの 3 施設の青年の家 (加須, 東松山, 岩槻) について行なう。

1. 地域利用者出現率の断面よりみた均等化の状況 複数施設設置による地域利用者出現率の均等化の状況 を断面によってみるため各施設間の距離をとって 2〜3 施設づつ重稀てみると東京都目黒区の老人クラブは図一 12〜19の上らに示せる。これを全般的に見ると，やは

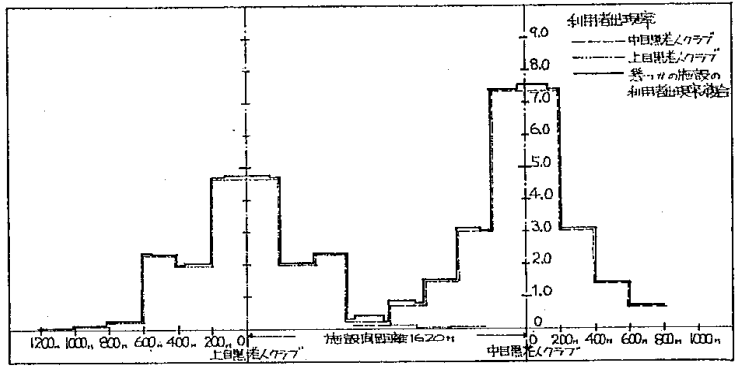

図一12上目黑一中目黑老人クラブ周辺の断面 から見た利用者出現率

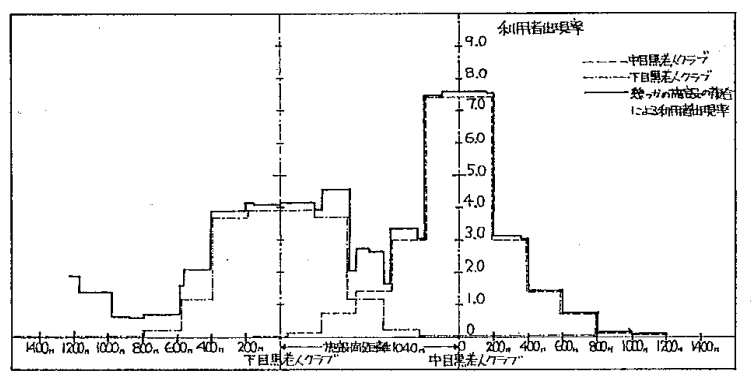

図一13 下目黑一中目黒老人クラブ周辺の断面 から見た利用者出現率

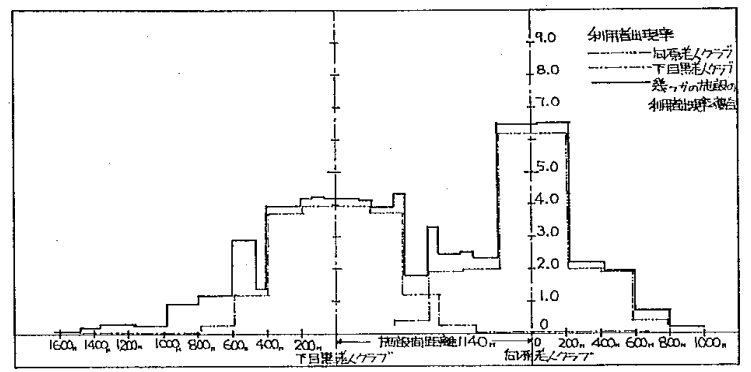

図一14 下目黒一向原老人クラブの断面 から見た利用者出現摔

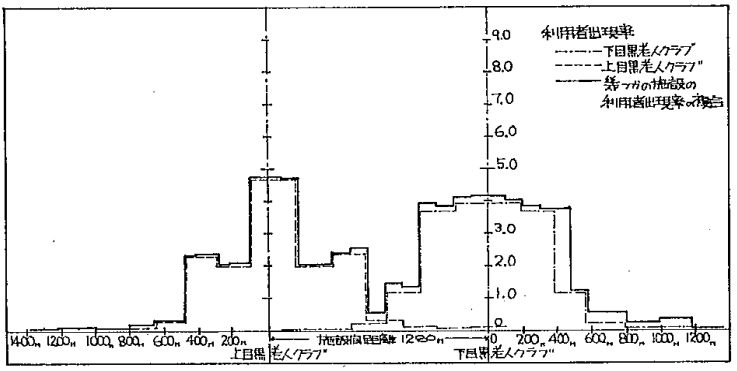

図一15 下目黑一上自黑老人クラブの断面 から見た利用者出現率

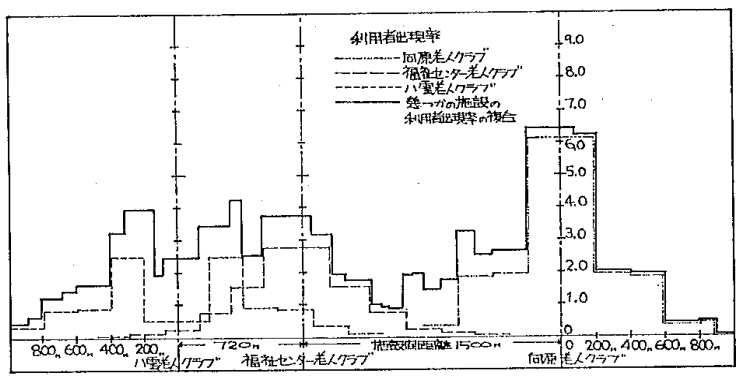

図一16 八雲一福祉センター向原老人クラブの断面 から見た利用者出現率 


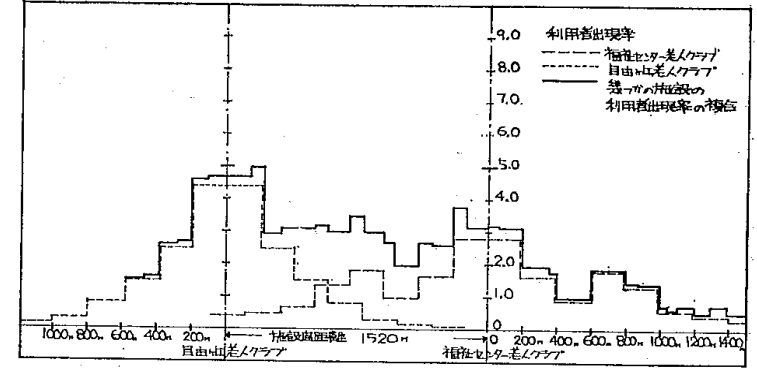

図一17 自由ケ丘一福社:せンタ一老人クラブの断面 から見た利用者出現率

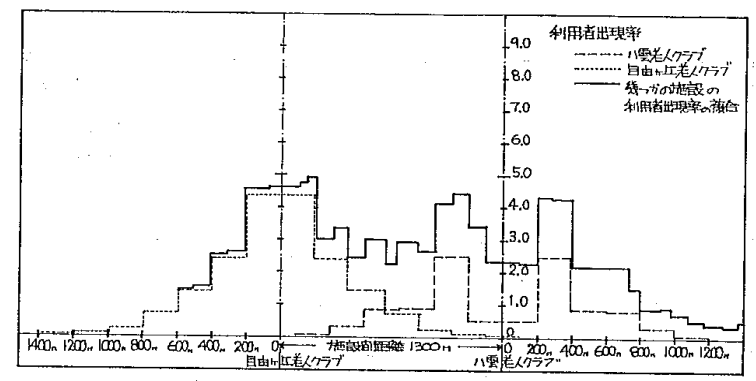

図-18 自由ア丘一八雲老人クラブの断面 から見た利用者出現率

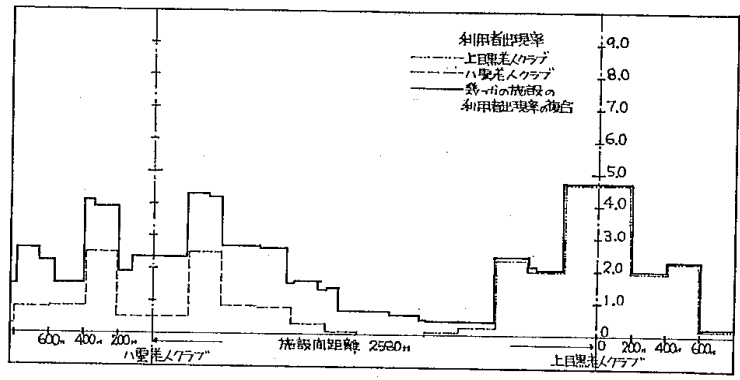

図一19 八雲一上目黒老人クラブの断面 から見た利用者出現染

り施設閒距離を小さくするほど利用者出現率の均等化が 详成されていると言える。しかし，複数施設の設置によ って施設と施設の間の部分は均等化されるが，施設の外 側における利用者出現率の低減が目立つ。これを補らた めにはかりに利用者出現率の最低を 1.0 とすると，一般 に区境界等から $600 \mathrm{~m}$ 程度の距離の所に施設を立地さ せる必要がある。さらに施設と施設の閒の人達は施設の 選択性があるのに対して, 施設の外侧の人達には選択性 がないので，その意味では施設と施設の間の均等化の最 低值よりさらに高い值を想定できる施設位置とする必要 がある。また，目黒区の中では老人クラブが比較的近い 距離に設置されている福祉センター老人クラブ，八雲老 人クラブ，自由ケ丘老人クラブの断面ではかなりよく均 等化されている。又各施設による利用者出現率差が問題 で，中目黒，上目黒，向原の老人クラブは，施設のごく 周辺が特に利用者出現率が高いため，他地域とどらして も利用者出現率の不均等が起っている。これはやはり各 施設の運営によって改善していく問題と言えよう。

次に老人クラブの場合に大規模化した場合の利用者出
現渌について比較するため，板橋老人福祉センター（福 祉センターという名称であるが老人クラブに若干機能回 復訓練の設備等が加わっている。）についてみると，板 橋老人福祉センターの利用者出現率は規模が目黒区の老 人クラブの 94〜5 倍でそれなりに施設周辺に执いては非 常に利用者出現率が高くなっているが，600 $\mathrm{m}$ 程度をす ぎると目黒区の老人クラブとあまり変わらず，均等化の 上では逆に大きく不均等を作っていると言える。

江東区読書室についてみると図一20～図一22 のよう に示せる。これを見ると富岡洲崎を除いて施設閒距離が 大きいため，ほとんど均等化されていない。また，各施 設の利用者出現率が施設周辺において高いため，施設間 距離をかなり小さくしないと全体的な均等化は計れない と言える。また, 施設の外側 (区境側) の利用者出現率 の低減が問題で，周辺の施設はかなり区境に近よせて $600 \mathrm{~m}$ 以内に押光る必要があるら。

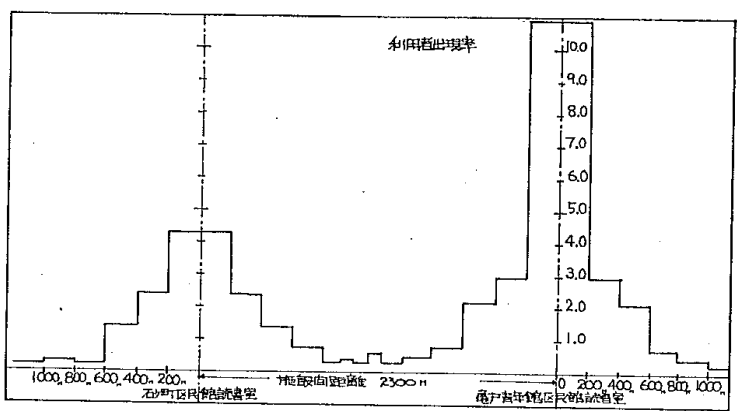

図一20 砂町区民館読書室一艘戸青年館区民館の断面 から見た利用者出現率

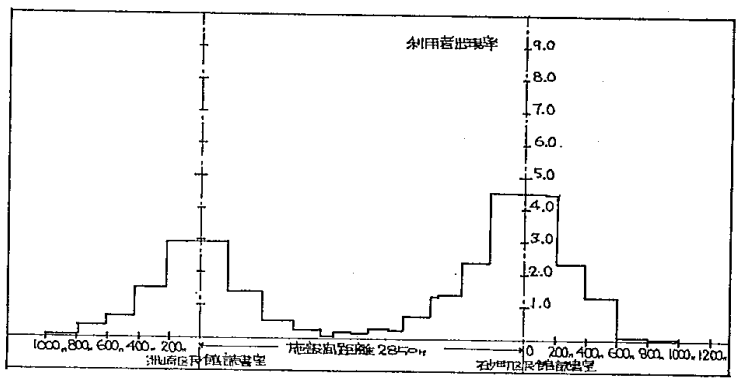

図一21 洲崎区民館読書室一砂町区民館読書室の断面 加ら見た利用者出現率

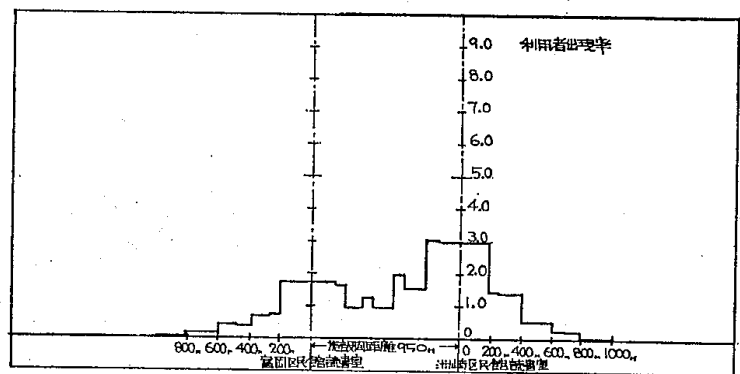

図一22 富岡区民館読書室一洲崎区民館読畫公の断面 加ら見た利用者出現率

次に大田区青年館と大田区働く青年の家についてみる と図一23 のように示せる。これらの施設 は大田区働く 青年の家は，利用者が名称のように勤労者のみに限定さ 
れており，同一の条件ではないが，一応青年層の施設と いらことで見ると，読書室の場合と同様に，施設間距離 が大きいためあまり均等化になっていない。また， 2 施 設のうち特に大田区青年館の利用者出現率が施設周辺で 高いため，施設間距離を小さくし，かつ大田区働く青年 の家の運営の改善を計らないと全体的な均等化は計れな いと言党る。また，前章の利用者出現率の最低 1.0 を碓 保するには現状の施設の運営形態ではかなりむずかしい と言える。

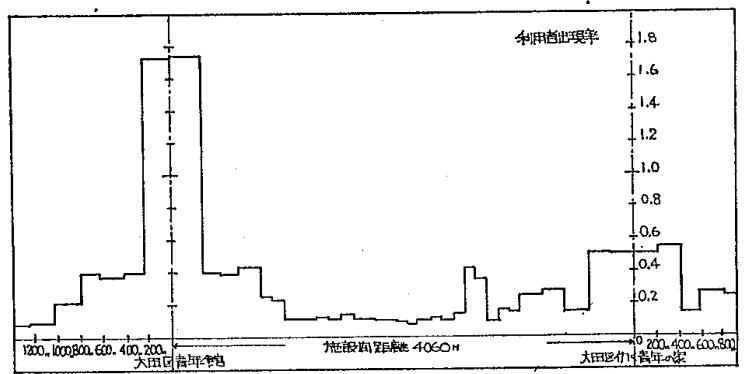

図一23 大田区青年館一働く青年の家の断面 から見た利用者出現率

次に埼玉県の青年の家について見ると図一24〜図一25 のように示せる。これを見ると，施設間距離が約 $20 \mathrm{~km}$ でめる加須一東松山青年の家, 岩槻一加須青年の家で は，施設と施設の閒の部分が比較的均等化されている。 これに較べて，施設間距離が約 $30 \mathrm{~km}$ である東松山一 岩槻青年の家では，施設と施設の間の部分の利用者出現 率の低下が目立つ。この 3 断面から判断した限りでは， 施設間距離は $20 \mathrm{~km}$ 程度なら施設間の低減する部分は 少なく，均等化化近いと言光る。この 3 施設の比較にお いては，施設間の距離と同時に施設による利用者出現率 の差が大きく，施設内容等によりこれを改善していくこ とも重要と言えよう。また施設の外側における利用者出 現率の低減も問題で，全体的には県境界等から $15 \mathrm{~km}$ 以内に押えることが望をしいと訔える。

以上のように老人クラブ, 読書室, 青年館と働く青年 の家，青年の家についての複数化の状沉を断面により見 たわけであるが,これによって複数化により施設間距離 を適当にとれば，施設と施設の間の部分は利用者出現率 の均等化がかなり達成できる。しかし，施設の外側の人 達の利用者出現率の低減に問題があり，区境界，県境界 等の行政上の境界からの距離にかなり注意して，施設を 設置する必要がある。さらには施設と施設の間の人達に は，施設の選択性など有利な条件があるので，施設の外 側の人達には若干高目の利用者出現率を想定できる位置 に設置するとこが望ましいと言える。また，各施設の利 用者出現率の差む問題で, 運営等において考慮する必要 がある。さらには積極的に利用者出現率を均等化するこ とを意図した運営上の考慮などが計られるとより望まし いと言える。また，施設の大規模化は利用者出現率の不

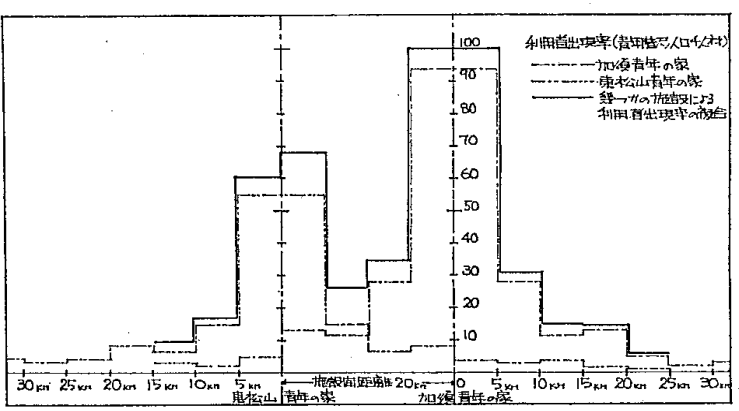

図一24 加須一東松山青年の家の断面から見た 利用者出現率

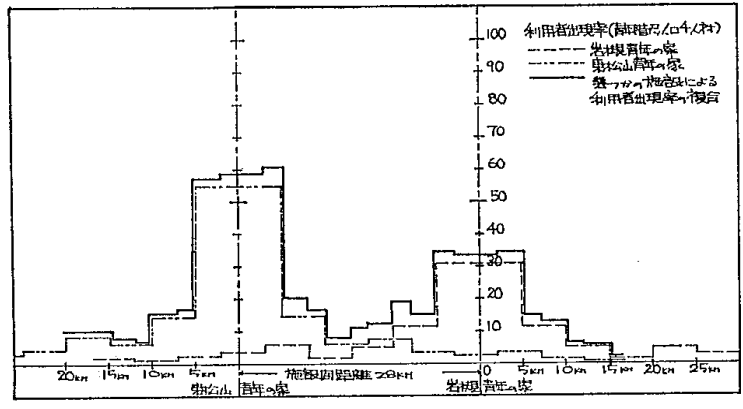

図一25 東松山一岩規青年の家の断面から見た 利用者出現率

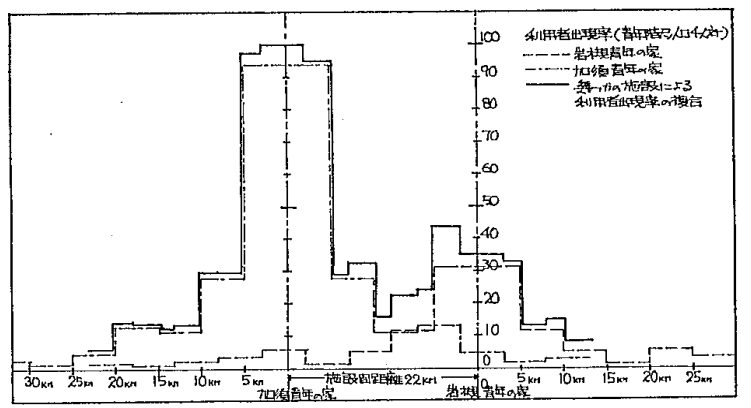

図一26加須一岩槻青年の家の断面から見た 利用者出現率

均等をさらに搪大する恐れがあり，大規模化に応じた運 営上の配慮がない場合は均等化の上で問題がある。

2. 地域利用者出現率の各地域の比較

複数施設設置による地域利用者出現率の均等化の状況 を見るため，実際の地図に各地域の想定される利用者出 現率を書き各地域の比較を行ならと, 東京都目黑区の老 人クラブについては，図一27 のよらに示せる。これを 見ると，現状の 7 施設によってサービスを受けていな い。またはサービスが少ない地域が明瞭で，今後の施設 設置の場所，順序等が明確にできる。また，施設の設置 位置が境界との関連で中途半端に立地している施設があ り，さらに外側に 1 施設設けるには狭い地域であるが， 現状では利用者出現率が少なすぎるなどの施設位置のま ずさを指摘できる。特に区境界で比較的鋭角に凸状に出 ている地域等がサービスを受けにくい地城として，十分 考慮を必要とする地域として指摘できる。逆に施設間距 離が適当で施設と施設の間にらまく利用者出現率の山が 


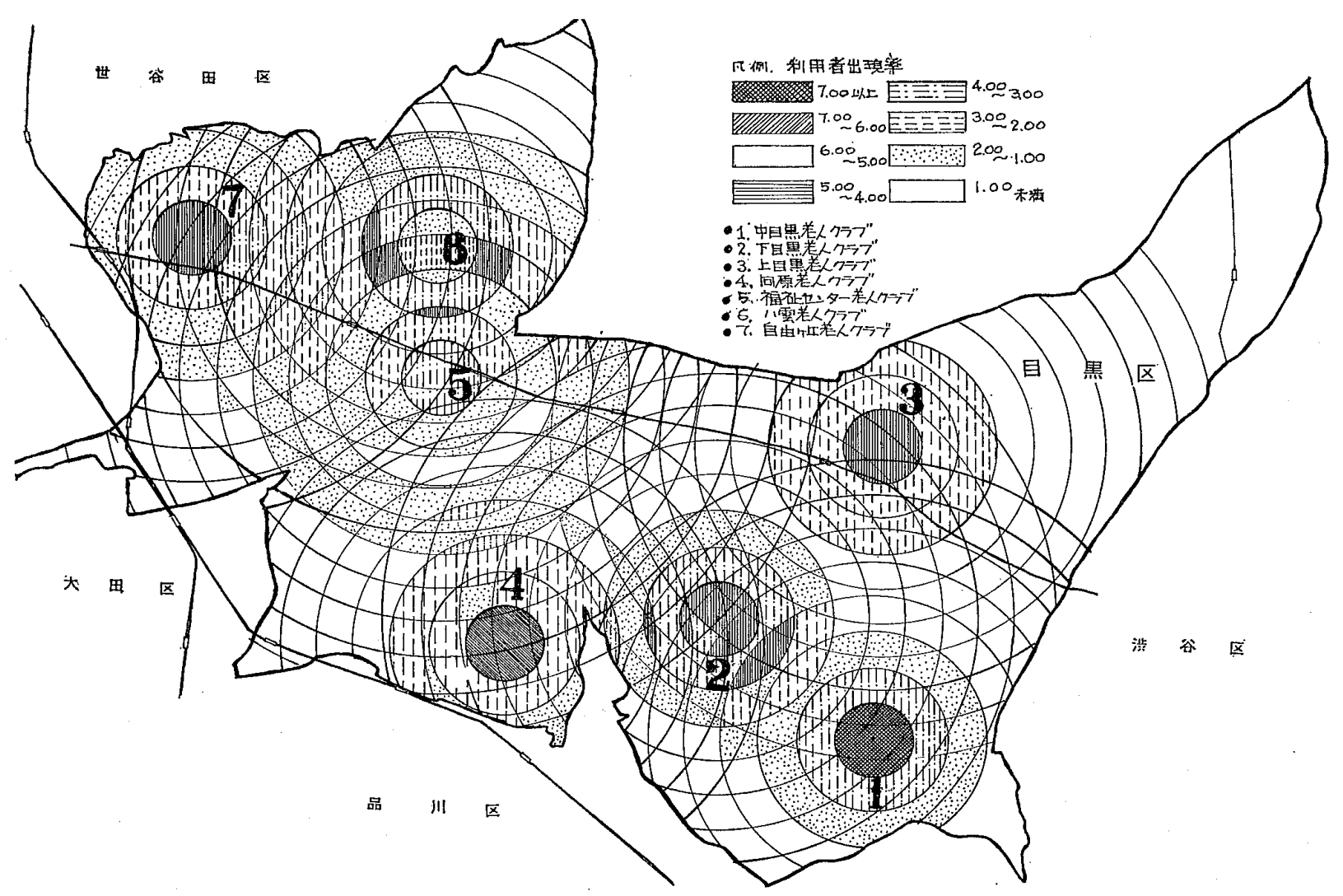

图一27 目黒区の老人クラブによる利用者出現率

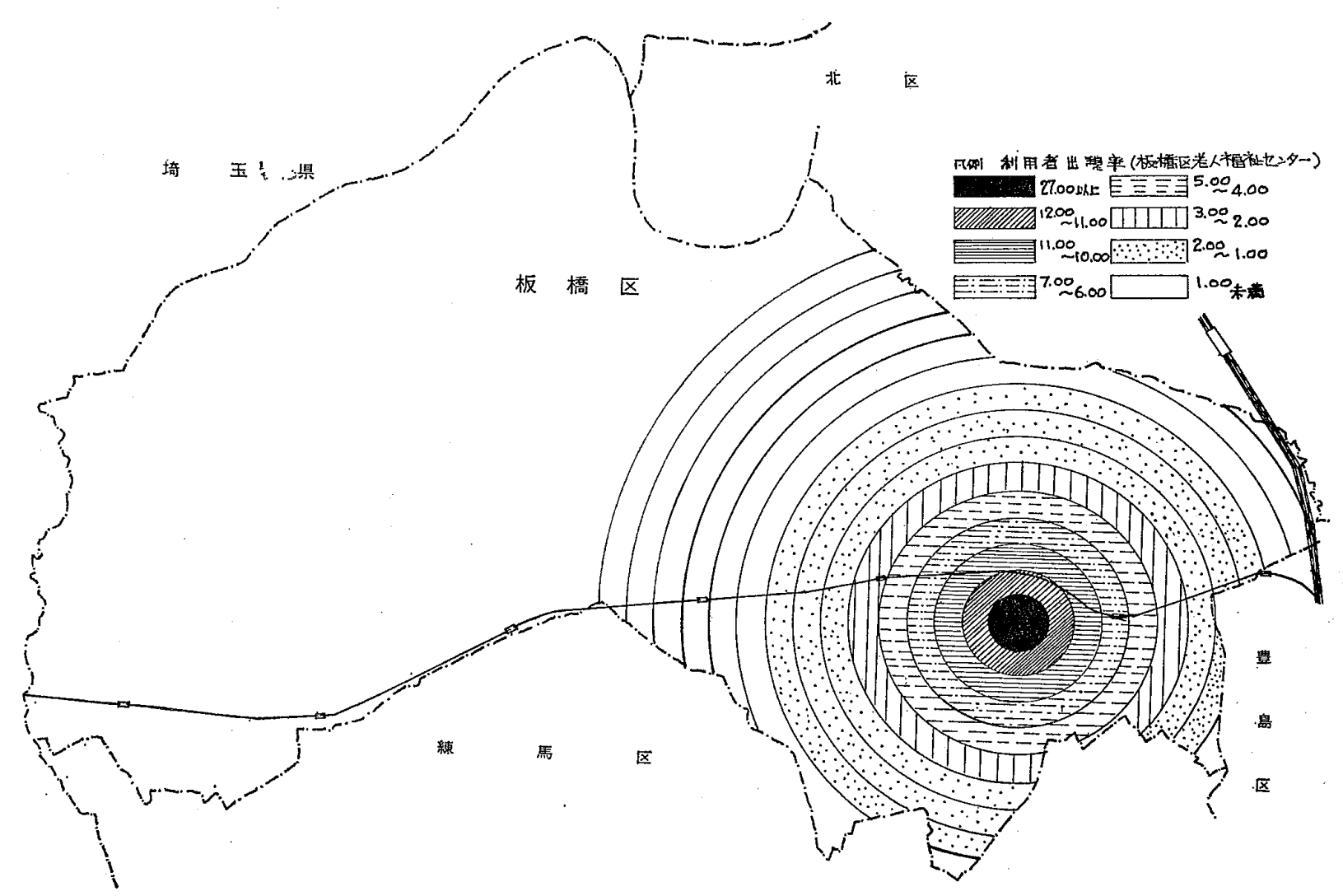

图一2B 板橋区の老人福祉センターによる利用者出現洓 
できている地域が何箇所か見ら れる。これは若干施設との距離 がある地域に選択性を与えて, 総体として利用者壮現率を増加 させる方法であり，複数化の效 果と言えよう。

また, 前記の大規模化の例と してもげた板橋区老人福祉セン タ一の例を見ると，図一28の よらになり，かなりの地域がサ 一ビス妾受けない地城として残 り，かつ利用者出現率の不均等 が明瞭である。このよらな大規 模化の場合にはやはりそれに伴 った運営（たとえば，バス等に よって利用者を集めるなど) 等 の考慮をしないと大規模化の効 果を十分生かしきれないと言え よう。

次に江東区の読書室について みると図一29 のよらに示せる。 これを見るとやはりサービスを 受けている地城とサービスを受 けていない地域，あるいはサー ビスが少ない地域が明瞭で，均 等化のためにはかなり各地域に 設置していくことが必要なこと がわかる。また，断面を分析し
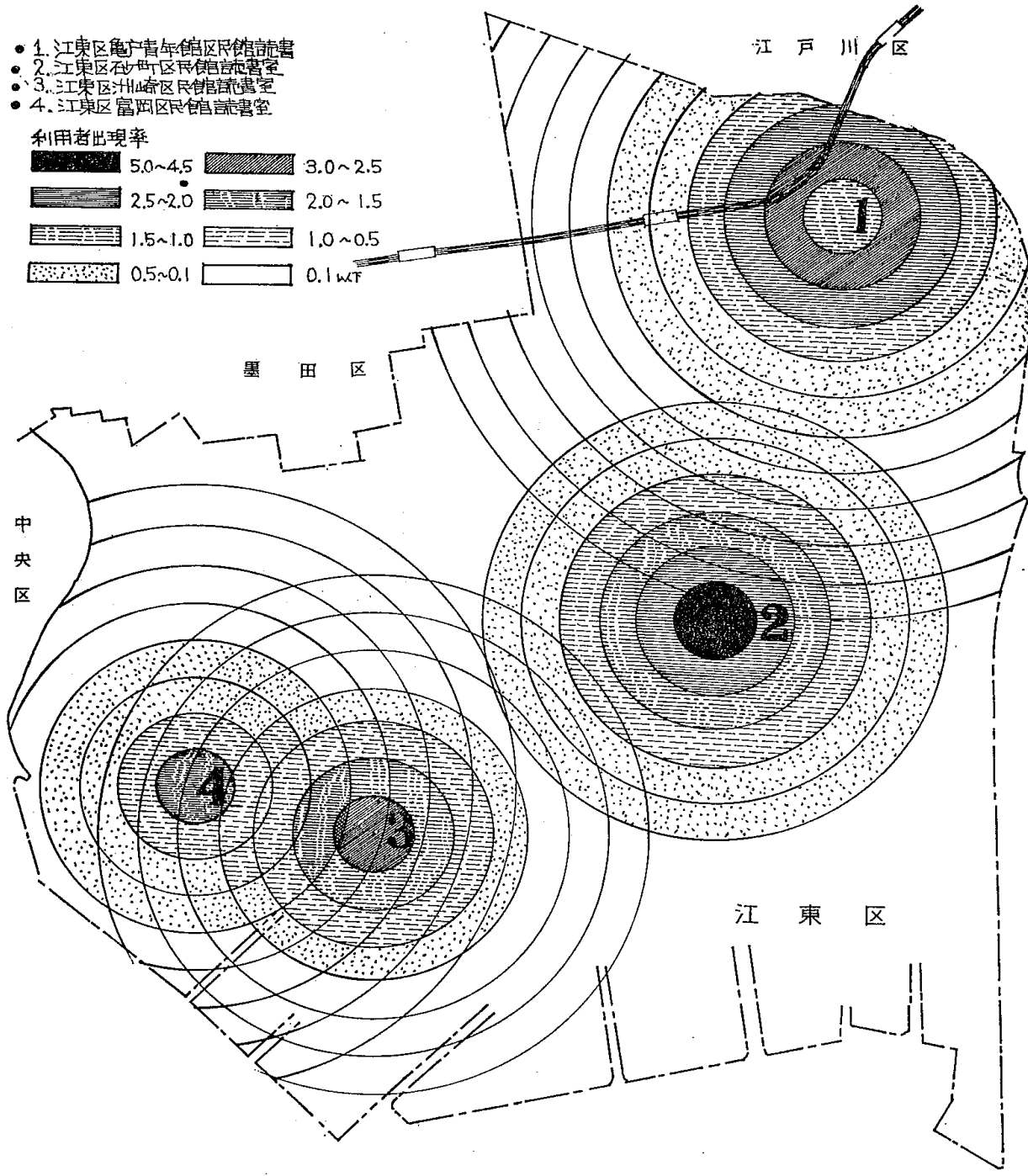

図一29 江東区の読書室による利用者出現率

たとき指摘したよらに施設間距離が大きすぎて複数化の 効果があまり見られない。さらに目黒区の老人クラブ同 様施設位置が区境界との関連で中途半端なものも指摘で きる。

次に大田区の青年館と働く青年の家について見ると 罒一-30 のように示せ，やはりサービスを受けている地 域とサービスを受けていない地域，あるいはサービスが 少ない地域が明瞭で，均等化のためにはかなり各地域に 設置していくことが必要なことがわかる。また，断面で 指摘したように施設間距離が大きいためあまり均等化に なっていない。さらに施設の外側の人達の利用者出現率 の少なさも指摘できる。また，複数化する場合でもこの よらに当初は施設数の少ない状態が推測でき，その場合 には区のなるべく広域をカバーできる交通条件を持った 地域に設置するなどの考慮が必要である。また，そのよ らな交通条件を持った地域がない場合は，運営の面でそ れに応じた考慮が必要とされよら。

次に埼玉目の青年の家の 6 施設のらち加須, 東松山・ 岩槻青年の家による利用者出現率を見ると図一31 のよ らに示せる。この図で左側には分析にとりあげなかった
青年の家があり，この地域は分析から除外する。また， 近年浦和に都市型青年の家ができており, 日㷌りの施設 で都市部の利用者を集めているが，ここでは除外した。 図を見るとやはり鋭角的な山部分の地域がサービスを受 けない地域として残されており，目黒区老人クラブにお いても指摘したように凸部分は比較的サービスを受けな い地域として残されてしまらことが応々にしてあり，当 初からの考慮が必要と言えよう。また，この例の場合も 施設と施設の間に若干利用者出現率が高くなっている部 分があり，複数化の效果があると言える。さらに断面で 指摘したよらに各施設の利用者出現率の差がある。これ は複数化の効果を減少させていること指摘できる。

\$4. ま ट め

（1）利用者出現率を均等に保つために，施設の複数 化による利用者出現率の最低を 1.0 として, 各種施設の 距離別平均利用者出現率汃施設間距離を求めると, 施 設間距離の大きい施設は青年の家，次いで老人福祉セン ター, 勤労青少年ホーム, 図書館, 览童館, 老人クラ ブ，体育館(一般公開), 読害室, 公民館, プールの順で ある。 


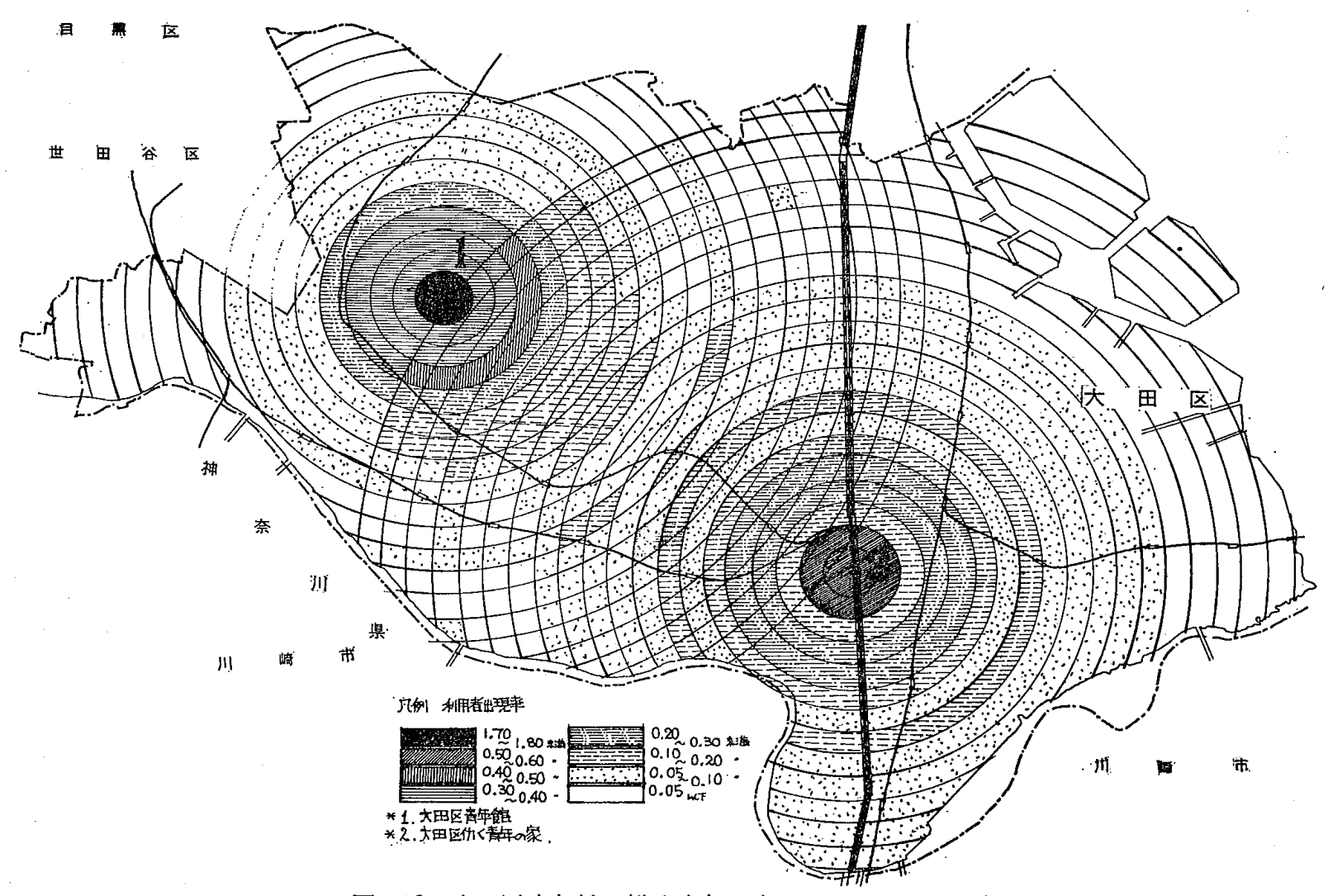

図-30大田区青年館と㗢く青年の家による利用者出現率

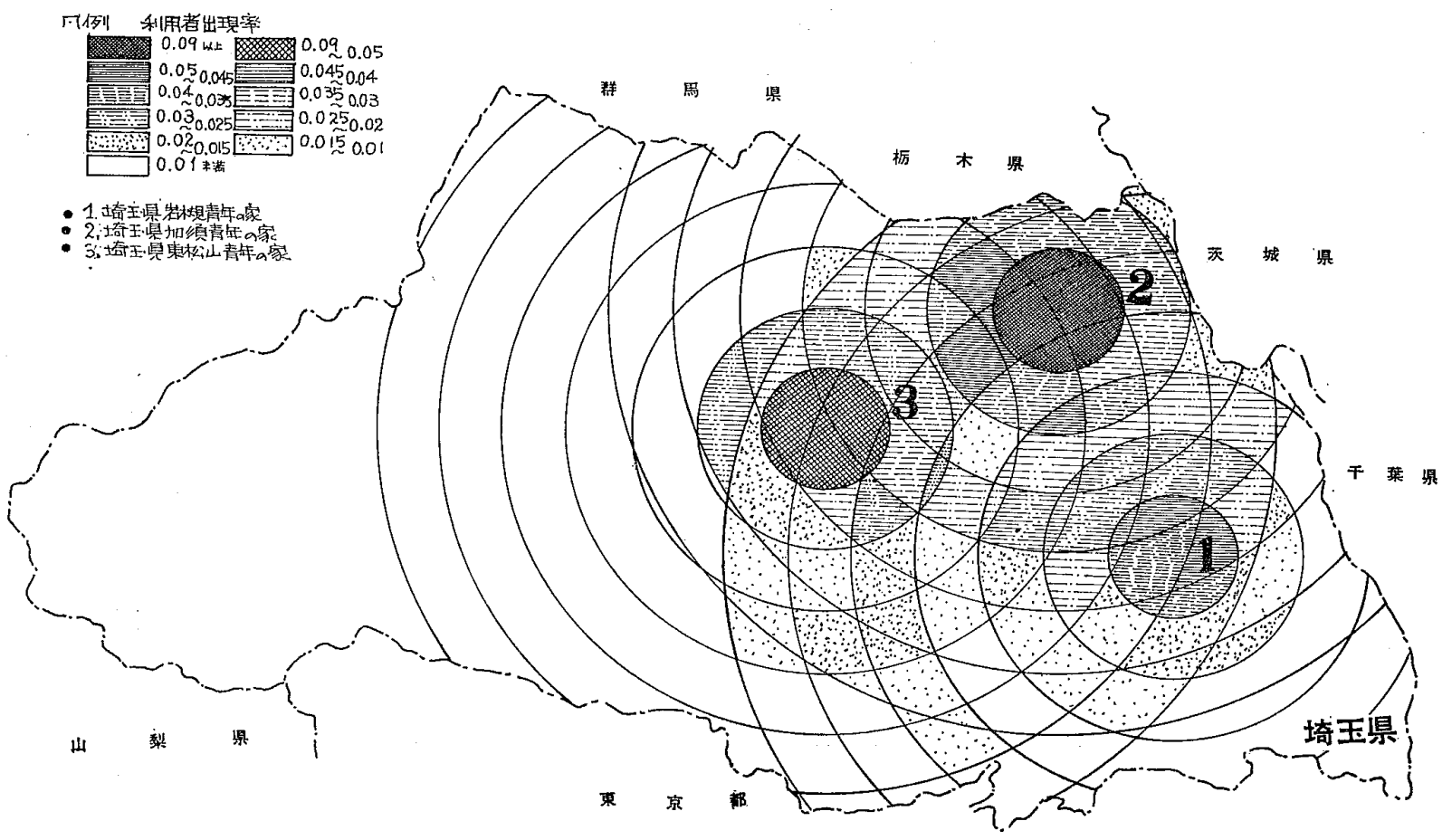

図一31 埼玉県の青年の家の利用者出現率

（2）施設の複数化による利用者出現率の均等化のた めに，利用者出現摔の最低を 1.0 とすると，1施設によ っては 0.5 を確保することになるが，その距離まで利用 者構成比率が過半を占めているのは読書室, 老人福祉也 ンター, 老人クラブ, 勤労青少年ホーム, 児童館で, こ れらの施設はいずれも個人利用施設である。逆に過半を 占めていない施設の中で青年館，青年の家，公民館はグ
ループ利用が中心で，また図書館，体育館 (一般公開)， プールは個人利用であるが過半を占めない。これはおも にその利用者が薄く広域に広がっているためでプールが 特にそうである。

（3）複数施設設置の実際の例について利用者出現率 を断面より見ると, 複数化による施設間距離を適当にと れば均等化がかなり達成できる。 
（4）複数施設設置の場合に，施設と施設の間でない 人達の利用者出現率の低減に問題があり，区の境界，県 の境界等の行政上の境界等からの距離に注意して施設を 設置する必要がある。

（5）複数施設設置の場合に，施設と施設の間の人達 には施設の選択性など有利な条件があるので，施設と施 設の間でない人達には，若干高目の利用者出現率を想定 できる位置に設置することが望ましいと言える。

（6）各施設による利用者出現率の差も問題で，運営 等において考慮する必要があり，さらには積極的に利用 者出現率が均等化するような，運営上の考慮などが計ら れるとより望ましいと言える。

（7）施設の大規模化は利用者出現率の不均等をさら に搪大する恐れがあり，大規模化に合った運営（交通便 利な位置への立地や施設のバスの運行なぞを行なわな いと大規模化の効果を発揮できないと言える。

（8）奏際の地図に各地域の想定される利用者出現率 を書き，各地域の比較を行ならと，サービスを受けてい る地域と受けていない地域，あるいはサービスが少ない 地域が明膫で，今後の施設設置の場所，順序等が明確で ある。

（9）区や県の境界からの施設の位置が中途半端に立 地している施設があり，さらに区や県の境界側に 1 施設 設けるには狭いが，現状のままでは利用者出現率が少な すぎるなど，施設位置のまずさを指摘できる。

（10）特に区境界，県境界等で鋭角に凸状に出ている 地域がサービスを受けにくい場所として十分考慮が必要 と言える。

(11) 施設間距離が適当で, 施設と施設の間にらまく 利用者出現率の山ができている地域が見られ，これは若 干施設との距離がある地域敒選択性を与えて, 総体とし て利用者出現䜌を增加させる方法として複数化の効果と 言える。

（12）複数化する場合に，当初は施設数の少ない状態 が推測でき，その場合には区のなるべく広域をカバーで きる交通条件を持った地域侸設置するなどの考慮が必要
とされよら。

末笔ながら本研究にあたり東京都立大学長倉康彦助教 授のご指導に媣甚の謝意を表します。また，資料を提供 していただいた各施設の方々に感謝の意を表します。

$<$ 関連資料 $>$

-地域児童厚生施設の利用者構成と利用圈域

1967 日本建築学会学術報告集

๑都区部青年館の利用率と利用内容

1968 日本建蚫学会学術報告集

・地域施設に拈ける読書室の便われ方

1968 日本建築学会学術報告集

๑都区部敬老館について

1968 日本建築学会学術報告集

-都区部青年館の利用距離と利用者分布

1969 日本建築学会学術報告集

・公立青年の家について

1969 日本建築学会学術報告集

- 勤学青少年ホームの施設内容と利用状況

1970 日本建築学会学術報告集

- 勤学青少年ホームの利用者棈成と利用距離

1970 日本建築学会学術報告集

- 公共社会教育, 体育, 福祉施設の設置状況と 建設費に関する一考察

1971 日本建築学会学術報告集

- 公共社会教育, 体育, 福社施設の経済的受益 に関する一考察（その1）

1971 日本建築学会学術報告集

- 公共社会教育, 体育, 福祉施設の経済的受益 に関する一考察 (その2)

1971 日本建築学会学術報告集

-公共社会教育, 体育, 福祉施設の運営維持管 理費の一考察

1971 日本建纂学会学術報告集

都区部青年館の使好れ方に関する研究 1971.11 日本建築学会諭文報告集 189 号

-公立青年の家の施設利用に関する研究(1)

1972.9 日本建築学会論文報告集

・公立青年の家の施設利用に関する研究(2)

1972.10 日本建築学会論文報告集

利用者出現率の均等化から見た施設配置計画 の研究(1)

日本建築学会論文報告集 (1973.2) 
U.D.C. 725.83.011.1

\title{
A STUDY ON ARRANGEMENTS OF AN ESTABLISHMENT WHICH DECREASES A DIFFRENCE OF UTHLIZATION-RATE, THAT IS THE RATIO OF USERS OF THE ESTABLISHMENT AMONG INHABITANTS
}

(Study No. 5, on the social education, welfare and physical education)

(See Page 94 of Trasaction of A.I.J. No. 204)

By AKIHIKo WATANABE, Graduate Student, Tokyo Metro. Univ., Member of A.I.J.

U.D.C. 725.51 .01

\section{ESTIMATING OF MEDICAL CARE NEEDS AND SETTING UP THE MEDICAL CARE SYSTEM IN AOMORI PREFECTURE}

- Study on areawide planning of medical care facilities, Part II-

By Dr. AKITOSHI MATSUMOTO, National Institute of Hospital Administration, Member of A.I.J.

Continuously Part I, I have tried to estimate medical care needs and to set up medical care system at each region. I have calculated the following and analysed difference of level at each region.

i) No. of impatient

ii) No. of bed required

iii) No. of outpatient

iv) Minimum needs expected (outpatient)

v) No. of outpatient per doctor (one person)

vi) No. of outpatient per other's proffessional staff (one person)

On the basis of the above-metioned data I have set up function of each hospital, and then I have proposed regionalized hospital system at each region.

U.D.C. 711.552 .001

\section{A STUDY ON CLASSIFICATION OF CITIES ACCORDING TO THEIR FEATURES OF DISTRIBUTION RATIO OF RETAIL SALES}

\author{
By TOSHIKATSU IWAMI, Graduate Student of Tokyo Institute
} of Technology Member of A.I.J.

I think that, the distribution ratio of retail sales in the city is related to the distribution of purchasing power, which is a good reflection of structure of the city. Then, I classify items of goods into some kinds of groups according to correlation of sales in a number of cities. As a technique of classification, I use a component analysis. In this way, I can find the co-ordinate systems that indicate profile values of items of goods on axes.

According to their features of distribution ratio of retail sales, each city is located on the co-ordinate systems. Thenn, through analysis of correlation of profile values of cities and indexes reflecting structure of cities, I think I can get impotant knowledges on planning of commerce in cities. 